\title{
UNIVERSITIES AND KNOWLEDGE: BRING THEM BACK TOGETHER!
}

\author{
Andraz Tersek
}

\section{doi: 10.18355/PG.2017.6.2.8}

\begin{abstract}
Signs indicating which way Slovenian universities have been taking to set and meet their social roles, give grounds for serious concern. Universities have been yielding to aggressive logic of the market, according to which - as a university teacher or a researcher-every individual is supposed to be worth only as much as the amount of money they are able to procure with their work in the market. Instead of defying the pure bureaucratic and brutally administrative conditions and criteria for the election and appointment of teachers and researchers, universities have been perfectly non-critically assuming this kind of dictates imposed by state agencies and committees. Academic professionals do not focus on the content and ethics of working processes in universities, but have become passive and apathetic slaves of robotised technocratic dehumanisation. Also because of this universities have been considerably failing to take care of the education of critically thinking citizens, of moral personalities and courageous civilian intellectuals empowered with authentic and quality knowledge. In view of what has been going on in universities, it is almost no longer possible to talk about the commitment of universities to ensuring and enhancing knowledge as a value.
\end{abstract}

\section{Key words}

universities, academic ethics, subordination to neo-liberal market logic, knowledge as a value

\section{Introduction - is knowledge still a value?}

Many people and many a university worker wonder why among the people of work and knowledge there is not more of the so-called civil courage. ${ }^{1}$ Also, why in the public space there are not more actively engaged and critical citizens. And why more young people do not take a more expressed and assertive attitude towards the themes that are not merely interesting and serious, but fateful in terms of culture and civilisation, perhaps even existentially significant? ${ }^{2}$ And why kind of velvet revolutionaries do not

\footnotetext{
${ }^{1}$ See Sruk 1995. See also »civic education«, »civic humanism « and « civil disobedience $\ll$ in Stanford Encyclopedia of Philosophy. Retrieved from http://plato.stanford.edu/ .

${ }^{2}$ See, for example, Balluch, 2011; Crouch, 2013; Hessel, 2011.

Slavonic Pedagogical Studies Journal, ISSN 1339-8660, Volume 6 Issue 2, September 2017
} 
emerge in larger numbers among the reflective people who at a certain point of the situation in the society know what it is about? Why is there not a massive and resolute response to the developments in the society, to this situation of (e.g. Aristotelian) massive nonthought and anti-politics? ${ }^{3}$ Last but not least also, why does it not come to massive and organised, nonviolent but resolute, genuinely democratic and thus more fateful protests and rebellions against the existing corporative lordship represented by (not politicians and statesmen but by) daily political administrators, (not rulers but) managers, 'the nobility'? Why have people been satisfied already with formal democracy instead of convincing and substantial democracy? ${ }^{4}$ This and similar questions have been asked increasingly frequently and we must be interested in them. Answers to them must be searched for. Also in - or especially at and by - universities. ${ }^{5}$

Although with potential discomfort due to modest efficacy, we must nevertheless be firm endeavouring for our own involvement in discursive search and reflective self-interrogation about life in the society, community, habitus, institutions, and the living situation of each individual. Doing this, university workers (also as intellectuals) ${ }^{6}$ ought to-most probablyadditionally pay special attention to the questions about the role and status of knowledge at universities and about the processes of education in general. As citizens we ought to desire, as workers at universities we should orient our critical attention not only at the question, but (and unfortunately) also the "problem" of university environment-also through the prism of my professional work, especially the Slovenian one. Many representatives of scientific sovereignty and academic dignity in Slovenia have done this. Convincingly. To what, with some additional conditions being fulfilledamong these conditions there is certainly organised joint action - could be general Slovenian intellectual discussion about university I have myself been trying to contribute in domestic public sphere, ${ }^{7}$ with no response whatsoever from the academy or the politics. I am convinced for such contribution one should endeavour all the time and at all levels of functioning.

\footnotetext{
${ }^{3}$ Starting from Aristotle's Nicomachean Ethics and Politics. See, for example, Kuzmanić 1996; Arendt 2006.

${ }^{4}$ See, for example, Žižek 2012; Crouch 2013. From the standpoint of constitutional philosophy see Bustamante \& Fernandes (Eds.), 2016.

${ }^{5}$ Comp. Freitag, 2010.

${ }^{6}$ Comp. Foucault, 2008; Sartre, 1981.

${ }^{7}$ Mainly in daily newspapers Pogledi, Objektiv, Mladina and Večer, but also in scientific journals, such as Revus and Poligrafi.
} 


\section{The hollowness of political promises, with some damaging measures}

Among the programme promises of the candidates in the last parliamentary elections and in those preceding them, who after the election formed the ruling coalition of political parties, those referring to the politics towards education and universities were exposed nearly with emphasis. The way they were by letter printed on programming and campaign paper, they seemed acceptable, partly even encouraging. Until today these promises have remained unfulfilled. ${ }^{8}$ The rhetoric of the ministers responsible for the department, who during this time have taken their turn in the position, is recognisably different from the rhetoric with which party leaders appeared in public during the time preceding the elections. Occasionally it is not just politically (in the sense of "policy") unconvincing and professionally inadequate, but also arrogant, even indecent.

Instead of a necessary developmental step forward during the period of the last six years a tangible step has been made to where it had seemed there was no way to - backwards. Primarily concerning the autonomy of universities (for instance their subordination to the rules and criteria adopted by state agencies and commissions), societal role and professional value of teachers (for instance concerning the policy of rewards, employment and promotion), funding of educational institutions, systemic legal arrangement of the basic segments of university study (for instance entrance criteria for study at university) and observation or consequent implementation of the constitutionally correct legal arrangement of funding and functioning of universities (with law, not with implementation rules). Some such criteria have for a long period of time also been explained in the decisions (precedents) of the Constitutional Court. These decisions still remain unimplemented, ${ }^{9}$ with the state advocating its politics towards universities with the slogan of necessary austerity measures also in this area - but doing this extremely unconvincingly. ${ }^{10}$

\section{Political indifference and academic passivity}

\footnotetext{
${ }^{8}$ I decided not to specifically mention the political candidates and parties by their name, also not to list their promisses, since they were abstract and remain unfulfilled. I refuse to give them any positive credit in this regard, and also refuse to promote them by writing down their names.

${ }_{9}^{9}$ Especially Constitutional Court's decision No. U-I-34/94. See Teršek \& Žgur, 2010.

${ }^{10}$ See, informativelly, The Higher Education Act, retrieved from http://pisrs.si/Pis.web/pregledPredpisa?id=ZAKO172 . For combined criticism of this Act by three public universities and one private in Slovenia see Rektorska konferenca Republike Slovenije (engl. Rector's Conference), retrieved from http://www.rkrs.si/ . Numerous articles and comments concerning Slovenian academic sphere can not be listed here.
}

Slavonic Pedagogical Studies Journal, ISSN 1339-8660, Volume 6 Issue 2, September 2017 
Many a fact and a number of characteristics of Slovenian university environment are an obvious and direct outcome of the legal policy of the state - or rather of inadequate policy. This keeps obviously and strongly interfering with the autonomy of universities. Not only with legal arrangement of teachers' salaries or conditions for state recognition of legal validity of university diplomas, also with legal arrangement of funding, Slovenian universities have kept being denied the autonomy explicitly warranted by the constitution. At the same time instead of by law the funding of universities keeps being arranged with implementation rules. Constitutional unacceptability of such situation is obvious. Also from the perspective of certain requirements of the state concerning the criteria that must be fulfilled so that universities can establish, change, and implement study programmes, which ought to be understood as the basic elements of the existence and functioning of universities, universities are not autonomous. In this area their autonomy is prevented by state agencies and commissions that in fact still approve the content of university programmes acting - as state administration in general —in an exaggeratedly formalistic, technocratically rigid and irritatingly bureaucratic way. ${ }^{11}$

Universities should firmly resist this-jointly and in an organised way. They should resist the dictate of the state and of all its agencies in all the questions that interfere with the very core of university autonomy and of its logical implementation; after all—and especially this seems to be extremely important - also concerning the criteria for the election of individuals into research and pedagogic titles. In this area universities have-under exactly this type of dictate by the state-uncritically adopted the system of unbearably formalised, unbalanced between the fields of sciences, intellectually uncritical and hyper-bureaucratic criteria inadequate for life, which have nearly nothing to do with the genuine content criteria for the assessment of the qualification of an individual to do research and to hold lectures. But they do not do this.

Universities should also resist the aggressive neo-capitalist market logic according to which an individual is supposed to be entitled to the recognition of the benefit for the university or to taking the chair in a faculty department or division — not if she or he is a sovereign expert in a certain field of science and a good lecturer, but only-if "with her or his work in the market she or he can procure inflow of money." Universities should also produce and publicly present a clear proposal for the change of systemic legal arrangement of the functioning and funding of universities that finally would

\footnotetext{
${ }^{11}$ Main representative of such pure-administrative legal politics and over-boureaucratic policy, but also - already vastly unberable - state of mind, is national agency NAKVIS (engl. Slovenian Quality Assurance Agency for Higher Education). Retrieved from http://www.nakvis.si/
} 
ensure them de facto, genuine autonomy. Until the universities have done this, they give legitimacy to the words of political decision-makers that universities do actually not wish autonomy in this area, that they do not feel competent for it, and that they do also not wish to take the responsibility for it. $^{12}$

But primarily can universities not afford internal functioning that would be ethical or even legally unbearable - for instance uncontrolled and unsanctioned cases of mobbing and victimisation, of plagiarism and other violations of copyright, paying remunerations for mentorship and membership in commissions for the defence of university authorial works or elections, obvious and severe disproportions in earnings, tolerating professors not consequently performing their educational obligations, attracting students by allowing shortcuts to examinations and degrees, establishing programmes or even faculties because of individuals or narrow groups of people and not because of compelling educational needs. At universities the most diligent, receptive and constructively critical students should also not be overlookedor even punished for their demonstrated critical and intellectual strain. To become and be an institutional example ought to be the categorical imperative of university environment.

This is why it would neither be appropriate if discussing the problems of universities, we were only focussed on the doings of day to day politics nor if these doings were exposed as all permeating reason for the problems of Slovenian universities or if the quality of educational, cultural, and research developments in universities was absolutely conditioned with them. In spite of everything, universities can still select (more) appropriate ways of raising their quality levels and of strengthening their societal role-primarily for the raising of the quality of educational process, which after all must be the central goal of universities. ${ }^{13}$

Not even for a moment should one doubt that in the framework of their unique function and privileged mission universities always share the responsibilities both for the state of mind in the society as well as for the general quality of social life, thus also for the substance of constitutional and social democracy we are living, as well as for the substance of discursive democracy, discussing constitutional and social democracy. ${ }^{14}$ So far in Slovenia there has been no lack of sovereign debaters on the themes about university, not only those who were actively involved in the discussions of the Committee for the Defence of Higher Education and Scientific Work.

\footnotetext{
${ }^{12}$ See Wallerstein, 2004; Galimberti, 2010.

${ }^{13}$ Back to the Enlightenment? See Cassirer, 1998.

${ }^{14}$ See, in detail, Teršek, 2014.

Slavonic Pedagogical Studies Journal, ISSN 1339-8660, Volume 6 Issue 2, September 2017
} 
With published newspaper articles, professional and scientific papers, as well as with books also other individuals have contributed significantly to the overall realisation of the intellectual and professional co-responsibility for the social status of knowledge and the functioning of Slovenian universities. ${ }^{15}$

\section{Study programmes between ballast and deceit}

Attempts to think university in relation to the situation and the developments that are currently defining it in our space reach beyond philosophical debates. They are controversies about very concrete university issues, academic problems and about calls to the state to establish a more appropriate attitude towards university. With discomfort we could say it is all about one and the same topic, self-interrogations, findings, and appeals.

In the public discussion about university politics in Slovenia to date a very important aspect of positioning the university into the framework of constitutional legislation - at least as far as I know-has nevertheless been completely overlooked. It has its roots in the recognisable and ethically questionable way how not only private educational institutions but also public universities make attempts with pragmatic and benefit seeking adaptability to the politics of the state primarily take care of increase in the number of enrolled students, their external image and superficial appeal of the supply of programmes at individual faculties, and, last but not least, the employability of teaching personnel, less, however, of the quality of education and employability value of knowledge. In consistence with the rigid computational mathematics of systemic rules and paperwork logic of defining remuneration criteria university teachers are simply paid according to the concrete number of above and below mentioned teaching hours in concrete study courses actually being carried out during an academic year.

The consideration of a faculty about introducing new study programmes and its decision for a concrete programme novelty can by all means result from professionally discerning and academic analysis of social need for experts in a certain field made in good faith, or from optimising content and personnel potential of the faculty. But it is possible to notice in Slovenian educational space this is not always the case.

In Slovenia it is possible to find and identify also university study programmes which seem to have been prepared surprisingly quickly, professionally less precisely, not quite well deliberated in terms of personnel, and inadequately logistically. It is even easier to find and identify study programmes that in practice do not follow the original predictions at

\footnotetext{
${ }^{15}$ But for the historical development of the University in Slovenia, see Benedetič, 1999.
} 
registration and guarantees to the first generations of enrolled students. In some programmes connoisseurs wonder whether they were not initiated by academically unconvincing employability and financial aspirations of a group of individuals rather than by potential academic insight or sincere consideration about societal need for individual professional profiles and having conscience about the responsibility for the quality of education.

In the context of some novelties in the supply of university studies in our country those programmes that either offer professional titles not even all the faculties themselves always know exactly what at the end are they supposed to mean in the sense of general and specific competences of graduates, or that address future students with promises of attaining a professional title, which in societal practice remain unrealised or even unrealisable, seem to represent a special problem.

\section{Positive constitutional legal obligations concerning the right to study}

Public authorities must therefore be reminded of the doctrine of positive constitutional legal obligations of the state. ${ }^{16}$ If the state, which in the process of establishing and accrediting study programmes has the final and decisive say, approves a study programme, it is in my view faced with the legal obligation to do everything that is necessary and reasonable to expect from the state in the labour market future students will personally experience the societal need and professional significance of the concluded study programme: with equitable possibility of applying for advertised vacancies and-in consequence — of employment. ${ }^{17}$

In other words: if the state approves a study programme of a certain occupational orientation, it must arrange the formalisation of this occupation in legal acts of the state (finally with publication in the Official Gazette) before the first generation of graduates has concluded their studies. Similarly, if at the moment when a programme that is-explicitly or according to the description of competences-clearly occupationally oriented comes into force, the state allows the founder or the provider to expect in good faith it will act in the same way as in the first case, i.e. assure a formal recognition of the occupation, it must also do so. In both cases, if the state does not fulfil its own positive legal obligation, it is an unconstitutional infringement of the autonomy of the educational institutions and of students' right to education, as well as of their right to work.

\footnotetext{
${ }^{16}$ Generally, see Mowbray, 2004.

${ }^{17}$ See, in more detail, Teršek, 2016.

Slavonic Pedagogical Studies Journal, ISSN 1339-8660, Volume 6 Issue 2, September 2017
} 
With the university study programmes that are not obviously occupationally oriented and are granted the permission of the state to be launched, the state is, on the basis of a positive obligation, perhaps really not responsible to explicitly equalise the degrees from such programmes with the professional titles from comparable programmes. It is, however, obliged to legally provide for options so graduates from such programmes can - as formally appropriate candidates-apply for publicly advertised vacancies with effective possibilities of being selected. If the state allows the implementation of study programmes that assure the graduates the winning of a certain professional title without equalising it with already existing occupational titles in programmes with comparable contents, it must nevertheless ensure graduates from such programmes will with equal rights be able to apply for all publicly advertised vacancies concerning jobs with comparable general and specific competences-irrespective of the professional field concerned: law, psychology, economy, management, architecture, anthropology, philosophy, or any other field. Omission of such positive (constitutional) legal obligations should be classified as unconstitutional conduct of the state. If an individual does not even get the opportunity to run for a particular job on an equal footing, his or her professional competences and personal qualities can also not be checked on the market.

284 The problem is probably even grater than it might seem at first glance. Let us, for instance, take the profession of a lawyer, journalist, or psychologist. Probably there are substantial and identifiable reasons why the state does not professionally equalise a graduate of a college or faculty of law and management with a graduate of a faculty of law. Or, why does it not equalise a graduate from a college or faculty of media with the profession of a journalist graduated from the Faculty of Social Sciences, or a graduate from a faculty of social and business studies with an economist graduated from the Faculty of Economics? Or, why does it not equalise a biopsychologist with the psychologists graduated in Maribor or in Ljubljana; and why is it, for instance, also not going to equalise the graduates from the study of psychosocial support in Nova Gorica with holders of the profession of a psychologist?

Probably from similar reasons the state also does not pass the legislation with which it would ensure vacancy notices are as a rule and only with rare, specially substantiated exceptions, composed in such a way as to address graduates from all substantively comparable study programmes and not only the holders of titles in formally regulated professions (psychologist, economist, journalist, lawyer, etc.).

The problem, which is obviously also legal in nature, escalates even further when graduates from a programme that on paper is supposed to be 
comparable with another, professionally regulated programme, cannot even transfer into this second one, or when transfer is not ensured to them even when they have passed a larger number of not exactly cheap payable bridging exams.

Such educational policy of the state and of universities should be deemed irresponsible. Lawyers should attentively consider the arguments about legal disputability of such behaviour and of the resulting consequences, which are extremely harmful for a growing number of young graduates. At enrolment a great majority of them, perhaps even all of them, together with their parents, do not know or do not understand well enough their professional title will not mean an occupational title and also that it will not grant them equality competing for jobs that can be explicitly read or implicitly recognise in otherwise carefully and convincingly composed descriptions of their assumed specific competences.

When such lack of information or even deception of students is also consequence of faculty leadership's conscious action, their hypocrisy, promotional cunningness, or even undoubtful misleading, in such approach to students lawyers should also recognize legal (criminal and compensational) liability of educational institutions as well as of persons in leading positions. In case faculties and students simultaneously identified themselves in the role of the impaired party, joint appearance before the court with a lawsuit against the state would be appropriate. In the time of crisis, when state politics allows the expansion of all kinds of study programs and titles, while employment opportunities for the young are less encouraging every day, Slovenian courts of law should remind the state of the content and significance of its constitutional legal obligations regarding the status of universities, the rights of students to education, and their right to employment - in the language of non-negligibly high compensations.

A society with such university policy and practice cannot claim to be a knowledge society. It is rather a society of a fateful interweaving of legal ignorance, political arbitrariness, economic brutality, and ethical perversion. It leaves the young within the reach of nihilism and a crisis of meaning. This is to be stood against.

\section{Commitment}

The signs which routes-within the room of freedom for independent decision-making and functioning - Slovenian universities have been selecting to reach this goal are not optimistic. They show universities do not care enough for the development of critically thinking citizens, of ethically conscious people, moral personalities and civilly courageous intellectuals 
motivationally empowered with knowledge. ${ }^{18}$ Universities do not take enough care for the development of self-respect of people who join into functioning community at universities. Universities still do not take enough care for knowledge as value, for morally grounded and rationally convincing education as something that in itself the goal of educational process (contrary to the assessment of the value of knowledge in relation to its bare value measured in the market). ${ }^{19}$ This concern, however, is far from being exclusively and completely dependent on the legal and political stance each respective day to day coalition authority takes in relation to universities.

The responsibility of universities for upgrading formal democracy with content is great and important. Universities will not be able to exercise these responsibilities without the necessary and constitutionally envisaged autonomy. But they will primarily not be able to exercise it without a firm commitment of all working at universities to ethically credible and legally proper functioning.

Authors remark: This article was introduced as a conference paper under the title „Universities are no longer what they ought to be“", at the $3^{\text {rd }}$ International Scientific Conference Pedagogy, Education and Instruction, held in Mostar (Bosnia and Herzegovina) on $21^{\text {st }}-22^{\text {nd }}$ October 2016. After being reviewed at the international level, paper has been accepted for publishing in the Conference Proceedings. They are planned by organizers to be released in the second half of 2017.

\section{Bibliographic references}

ARENDT, H. 2006. Med preteklostjo in prihodnostjo. Sest vaj v politicnem misljenju. Ljubljana: Zalozba Krtina.

BALLUCH, M. 2011. Upor v demokraciji. Drzavljanjska nepokorscina in konfrontacijske kampanje. Ljubljana: Zalozba Krtina.

BAUMAN, Z. 2016. Postmoderna etika. Ljubljana: Znanstvena zalozba Filozofske fakultete Univerze v Ljubljani.

BENEDETIC, A. 1999. Poti do univerze. Ljubljana: Studia Humanitatis.

BLAIS, M.C. - GAUCHET, M. - OTTAWI, D. 2011. O pogojih vzgoje. Ljubljana: Zalozba Krtina.

BUSTAMANTE, T. - FERNANDES, B. G. (Eds.) 2016. Democratizing Constitutional Law. Switzerland: Springer.

CASSIRER, E. 1998. Filozofija razsvetljenstva. Ljubljana: Claritas.

CROUCH, C. 2013. Postdemokracija. Ljubljana: Založba Krt.

\footnotetext{
${ }^{18}$ In genuine educational sense. See Blais, Gauchet \& Ottavi, 2011.

${ }^{19}$ In order to safeguard and develop one's empowerment and ableness for being a critical person, critical-thinking citizen, active political individuum and morally sovereign person, being able of authonomous moral and rational political decision making. See Haidt, 2012; Bauman, 2016.
} 
FOUCAULT, M. 2008. Vednost-oblast-subjekt. Ljubljana: Zalozba Krtina. FREITAG, M. 2010. Brodolom univerze in drugi eseji iz politicne epistemologije. Ljubljana: Zalozba Sophia.

GALIMBERTI, U. 2010. Grozljivi gost. Mladi in nihilizem. Ljubljana: Modrijan.

HAIDT, J. 2013. Pravicniski um. Zakaj dobre ljudi ločujeta politika in religija. Ljubljana: Umco, Penca in drugi.

HESSEL, S. 2011. Dvignite se! Ljubljana: Zalozba Sanje.

KUZMANIC, T. 1996. Ustvarjanje antipolitike. Ljubljana: Znanstveno in publicisticno sredisce, Zalozba Sophia.

MOWBRAY, A. 2004. The Development of Positive Obligations under the European Convention on Human Rights by the European Court of Human Rights. Oxford and Portland, Oregon: Hart Publishing.

SARTRE, J. P. 1981. Filozofija-estetika-politika. Ljubljana: Cankarjeva zalozba.

Stanford Encyclopedia of Philosophy. Available online: http://plato.stanford.edu/ .

TERSEK, A. 2014. Teorija legitimnosti in sodobno ustavnistvo. Koper: Univerzitetna založba Annales.

TERSEK, A. 2016. Pravna ignoranca skodi. Koper: Univerzitetna zalozba Annales.

TERSEK, A. - ZGUR, M. 2010. (FinanCna) avtonomija univerze. Ljubljana:

Revus-revija za ustavno teorijo in filozofijo prava.

WALLERSTEIN, I. 2004. The Uncertainties of Knowledge. Philadelphia, USA: Temple University Press.

ZIZEK, S. 2012. Zivljenje v casu konca. Ljubljana: Cankarjeva zalozba.

Assoc. prof. dr. Andraž Teršek

Departments for Constitutional Law, Educational Sciences, Media Law, Politology and Public Health Law and Ethics

University of Primorska, Koper and University of Nova Gorica (both in Slovenia)

Klavčičeva 9, 1241 Kamnik

Slovenia

andraz.tersek@gmail.com 